\title{
What Drives Terrorist Innovation? Lessons from Black September and Munich 1972
}

\author{
Authors: \\ Andrew Silke, Cranfield Forensic Institute, Cranfield University, Shrivenham, UK. \\ E-mail: a.silke@cranfield.ac.uk \\ Anastasia Filippidou, Centre for International Security and Resilience, Cranfield University, \\ Shrivenham, UK.
}

\begin{abstract}
Understanding terrorist innovation has emerged as a critical research question. Terrorist innovation challenges status quo assumptions about the nature of terrorist threats and emphasises a need for counterterrorism policy and practice to attempt to not simply react to changes in terrorist tactics and strategies but also to try to anticipate them. This study focused on a detailed examination of the 1972 Munich Olympics attack and draws on the wide range of open source accounts available, including from terrorists directly involved but also from among the authorities and victims. Using an analytical framework proposed by Rasmussen and Hafez (2010), several key drivers are identified and described, both internal to the group and external to its environment. The study concludes that the innovation shown by Black September was predictable and that Munich represented a profound security failure as much as it did successful terrorist innovation.
\end{abstract}

Keywords: terrorism, terrorist innovation, Munich 1972, Black September 


\section{Introduction}

A growing body of research has attempted to identify and understand the factors associated with innovation in terrorism (e.g. Dolnik, 2007; Rasmussen and Hafez, 2010; Horowitz, 2010; Jackson and Loidolt, 2013; Gill, 2017; Rasmussen, 2017). In part this increased attention reflects a concern that more innovative terrorist campaigns might potentially be more successful and/or simply more dangerous. Successful counterterrorist measures and target hardening efforts render previous terrorist tactics ineffective, forcing terrorists to innovate and adapt in order to overcome countermeasures. To paraphrase Herwig, a precondition of innovation is a concrete problem which organizations have a vital interest in solving, and the key determinant of innovation success rests in the specificity of the problem, the solution to which would offer significant advantages (1998, pp.311-312). Terrorist groups use innovation both instrumentally to plan and conduct attacks, but also in a symbolic way to communicate a message of fear and coercion. Consequently, terrorists' use of innovation is a means to an end, but is also an indicator of the objectives, style and condition of the group.

Terrorist groups demonstrate an apparent ability to develop and employ novel methods of attack. However, often these innovations do not always, or even usually, involve the introduction of new technologies or means, but can rather signify a different and original utilisation of existent means. These constant efforts from terrorist groups to stay a step ahead of security forces (and of each other) have led towards a combination and synchronisation of existent methods and tactics in order to gain the best advantage and achieve the best results for them (Afzal and Filippidou, 2017. p.32). 
Terrorist groups with clear aims and objectives and with a sense of urgency to attain their goals within their lifespan are likely to demonstrate a high level of innovation, as such organizations are generally more inclined to constantly improve their capabilities until they find the most effective mode that will yield the desired results (Afzal and Filippidou, 2017. p.13). As highlighted by the Homeland Security Institute (2007, pp.90-91) terrorist innovation is of particular concern because:

Innovation appears to provide an element of surprise important for successfully executing an attack, particularly where there are stringent security measures. ... Innovation can also have an impact in the form of media coverage - such attacks tend to garner more publicity than the repeated use of a standard tactic. ... Innovation also can result in psychological impact by adding a new dimension of vulnerability to the target population's psyche.

Weinberg (2008) highlighted that terrorist innovation was a critical issue that demanded more research attention. He warned that "Innovative terrorist groups seem to be exceptionally dangerous. Their innovations are often emulated by other groups - even ones with other aims and in other parts of the world." Terrorist innovation, then, certainly challenges status quo assumptions about the nature of the terrorist threat and emphasises a need for counterterrorism policy and practice to attempt to not simply react to changes in terrorist tactics and strategies but also to try to anticipate them (e.g. Faria, 2006). A variety of studies have also highlighted that many particularly high impact terrorist attacks appear to have been highly innovative, a link which has emphasised the need for greater understanding about how and why innovation occurs in terrorism (e.g. Rasmussen and Hafez, 2010; Hafez and Rasmussen, 2012). 
The main focus for research to date on this subject has been to explore terrorist decision-making processes (e.g. Moghadam, 2013; Knight, Keane and Murphy, 2015; Tishler, 2017), creativity within terrorist groups (e.g. Cropley, Kaufman and Cropley, 2008; Gill, Horgan, Hunter and Cushenbery, 2013; Gill, 2017) and learning by terrorists (e.g. Jackson, Baker and Cragin, 2005; Ranstorp and Normark, 2015; Kettle and Mumford, 2017; Goerzig, 2019). These efforts often overlap and are not mutually exclusive. The different approaches tend to explicitly recognise the planned and relatively organised nature of terrorism. In this regard, several researchers have also noted the value of using a rational choice perspective in trying to understand and respond to terrorist planning and decision-making, and studies have already identified the rational basis behind terrorist decision-making and how these can identify possible points of intervention to prevent or disrupt effective operations (e.g. Taylor, 1988; Jacobs, 1998; Silke, 2003; Clarke and Newman, 2006; Newman and Hsu, 2012; Hsu and Apel, 2015).

This approach draws heavily on the rational choice framework used in many studies of criminal behaviour. At the heart of the approach is the concept of the 'reasoning criminal'- "one who employs the same sorts of cognitive strategies when contemplating offending as he and the rest of us use when making other decisions" (Cornish and Clarke, 1986, p.v). This has led to an enormous literature on situational crime prevention which has stressed the importance of environmental factors affecting offender decision-making. Explicitly built into the criminological rational choice models is a recognition that there are gaps in the knowledge and skills of the offender, as well as clear limits to the resources offenders could devote to the planning, preparation and active decision-making for any one crime.

This has been recognised in studies of terrorist decision-making, with Drake's (1998) highly influential research drawing attention to five key factors which affected terrorist tactics: (1) 
Quality of leadership, (2) Quantity of members, (3) Quality of members, (4) Weapons available, and, (5) Financial base. Drake's analysis highlighted that there were clear limits to terrorists' capabilities. While terrorists may have highly ambitious aims, they face practical limits to what they can do. Nevertheless, innovation within these limits poses a serious challenge, and raises important questions about what factors facilitate or inhibit innovation within terrorism.

\section{The Current Study}

In order to identify these factors, several past studies of terrorist innovation have focused on detailed case studies to draw out important points from what have usually been high profile terrorist attacks (e.g. English, 2013; Moghadam, 2013). This current study adopts a similar approach, focusing attention on the Black September attack against the Munich Olympics in 1972. This was unquestionably one of the most significant terrorist attacks of the $20^{\text {th }}$ century. In analysing innovation in this attack, this study adopts the analytical framework proposed by Rasmussen and Hafez (2010) which recommended that innovation could be assessed along a variety of major themes. Two of the key thematic factors (1) Preconditions and (2) Causes provide the framework here for analysing the Munich attack. Preconditions are the background factors relating to the characteristics of the environment or of the terrorists themselves (e.g. the qualities identified by Drake around leaders, members and other resources) which make innovation more or less likely. Causes are those factors directly linked to the specific decision to innovate, and might, for example, relate to a changed security environment or competition between rival terrorist groups. Importantly, causes in this context, does not refer to the root causes of a conflict. 
The Black September attack against the Munich Olympics in 1972 has fairly been described as a watershed moment in modern terrorism, a game changer which permanently shifted the dynamics of both terrorism and counter-terrorism (Taylor, 1993). Arguably, only 9/11 has been a more significant terrorist attack since then. The number of people killed in the attack was not massive - seventeen in total - a toll which is not high enough for the event to gain entry into the list of the 1000 most lethal terrorist attacks since $1970^{1}$, yet the impact of Munich was greater than virtually all other attacks in that particular list (again the notable exception being 9/11). Bruce Hoffman (1998 p.71) correctly described Munich as "the premier example of terrorism's power to rocket a cause from obscurity to renown" and indeed the massive media impact of the attack turned what in one perspective could be seen as a near-complete failure all the terrorists were killed or captured and the Israeli government did not give in to any of the terrorists' demands - into what was in fact universally seen as a significant success for Black September and the broader Palestinian resistance movement.

Indeed, writing in 2002, Abu 'Ubeid Al Qurashi, an Al-Qaeda activist drove home the view that as far as other terrorists were concerned, Munich is still seen as an astoundingly successful attack:

Seemingly, the [Munich Olympics] operation failed because it did not bring about the release of the prisoners, and even cast a shadow of doubt on the justness of the Palestinian cause in world public opinion. But following the operation, and contrary to how it appeared [at first], it was the greatest media victory, and the first true proclamation to the entire world of the birth of the Palestinian resistance movement ... 
In truth, the Munich operation was a great propaganda strike. Four thousand journalists and radio personnel, and two thousand commentators and television technicians were there to cover the Olympic Games; suddenly, they were broadcasting the suffering of the Palestinian people. Thus, 900 million people in 100 countries were witness to the operation by means of television screens. This meant that at least a quarter of the world knew what was going on in Munich; after this, they could no longer ignore the Palestinian tragedy. ... There are data attesting to the importance of the Munich operation in the history of the resistance movement, and the extent of its influence on the entire world. It is known that a direct consequence of this operation was that thousands of young Palestinians were roused to join the fedayeen organizations... The number of organizations engaging in international 'terror' increased from a mere 11 in 1968 to 55 in 1978 . Fifty-four percent of these new organizations sought to imitate the success of the Palestinian organization - particularly the publicity the Palestinian cause garnered after Munich (Al Qurashi, 2002).

Given the incredible impact of the Munich attack - an achievement that no attack before it matched and arguably only one since has surpassed - this incident is well worth analysing in any study of terrorism.

The Black September Organisation (BSO) was formed as a defacto offshoot of the the Palestinian Liberation Organisation (PLO) in 1971. The BSO's function initially was to wage a war against the Jordanian Monarchy. The very formation of the BSO was the result of innovation, as the organisation's point was to enhance the PLO's adaptability, flexibility, and deniability. The organisation had a collective leadership, which drew primarily upon existing Fatah (and to a lesser extent Popular Front for the Liberation of Palestine (PFLP)) 
membership. Fatah itself was originally established in 1959 under the leadership of Yasser Arafat and others, as a militant political nationalist movement for furthering the Palestinian cause (Sayigh, 1997). By the end of the 1960s, Arafat and Fatah had effectively taken over the PLO, with Fatah often being described as the PLO's defacto military wing though it also played an important political role (Kurz, 2005). Under this arrangement, Fatah was able to orchestrate a long-running campaign of violence initially targeting Israel but gradually (and sporadically) spreading to other countries who were perceived to be opposed to the movement or supportive of its enemies.

The leaders of the BSO included Abu Iyad, Abu Daoud, and Ali Hassan Salameh, who were also senior Fatah leaders (Dobson, 1974, p.51). Black September was separate from Fatah, in order for Fatah and the PLO not to have to carry opprobrium for their operations (Reeve, 2001, p.41). The BSO was responsible for its own actions, which would not compromise the leadership of the PLO.

Studying Munich also offers analysts other advantages. To begin with, there is a relatively rich source of information to draw upon. In the forty years since the attack many of the key players in the incident, not only in the terrorist camp but also among the Germans and Israelis, have given extensive interviews about what happened. Two of the most important terrorist commanders directly involved in the incident, Abu Iyad and Abu Daoud, have separately published autobiographies where they discuss Munich in detail (Iyad, 1981; Daoud 2002). Other terrorists involved have also given informative interviews and accounts of what happened. The attack has also been the focus of detailed investigative journalism which has produced some high quality accounts of the event (in particular those of Taylor (1993), Reeve 
(2001) and Klein (2005) stand out), as well as some notable academic analysis (e.g. Sanan, 1996; Schiller and Young, 2010).

Thus, in some respects, analysis is considerably helped by a wide range of available sources. One problem, however, is that the sources are not consistent and many details about what happened are disputed. In some cases, there are inconstancies and contradictions even in the accounts provided by the same source. Notable in this regard is Abu Daoud, one of the senior terrorist leaders involved. He has provided many interviews regarding Munich over the past forty years as well as providing an autobiography. These accounts are largely very consistent over the four decade period with one exception. One of his accounts which is often quoted extensively was provided in 1973 following his capture by the authorities in Jordan. While he was detained, Abu Daoud was severely tortured and was then forced to make a series of radio broadcasts at the behest of the authorities. While all sources agree that this information was obtained through torture, and most view it as deeply unreliable, a few still give great credence to this account. In the assessment here, however, the torture account is viewed as unreliable and instead greater weight is given to the substantial accounts that Abu Daoud provided in other contexts (which it should be noted are also generally much more consistent with the accounts provided by other terrorists involved in the attack).

A further gap in understanding is that Munich is surprisingly poorly served with regard to official reports into what happened. Unlike $9 / 11,7 / 7$, and many other high profile terrorist attacks, there was no major public enquiry carried out in the aftermath of Munich and no highly detailed official account as to what had happened. The German authorities had a few brief afteraction reports which were generally kept classified. For many years they denied that they had even kept any official records or documentation regarding Munich, a claim which was only 
exposed in the early 1990s when the persistent probing by the victims' families finally forced the release of some documentation. Israel did conduct an enquiry and produced what was called the Kopel report into the incident. This though was a mere 15 pages in length and was kept classified until 2005.

\section{ATTACK OVERVIEW}

Perhaps one of the most surprising features of the Munich attack was just how late planning for the assault started. Black September only decided to try and target the Games at a meeting in Rome on July 15th 1972, barely 6 weeks before the Opening Ceremony (Wolff, 2002). While this was relatively late in the day to start planning for what would ultimately become such an extraordinary attack, Black September nonetheless still had some reasons to be optimistic. As a group, the organisation had considerable resources to draw upon. Israeli intelligence later judged that at least 40 people were involved in the planning, preparation and execution of the attack. Black September also had the benefit of experience and had carried out a number of other successful terrorist attacks in Europe in the run-up to Munich, including three in West Germany earlier that year. The late decision to target the Olympics also provided a further benefit to the attackers as it reduced the potential intelligence leakage or signals that a major operation was in preparation. The late decision meant that the potential window for interception or detection was significantly reduced.

The terrorist group was also greatly helped by the fact that security surrounding the Munich Games was desperately lax. Indeed, Munich is now widely regarded within security circles as an example of what not to do on almost every level when it comes to protecting major events such as the Olympics. Although at least one German security planner had specifically raised a 
terrorist hostage event as one of the risks facing the Games, this had been dismissed by senior figures as far-fetched and no serious precautions or preparations were made (Wolff, 2002). Black September had little difficulty taking advantage of this as they prepared for the attack. Indeed, in the weeks prior to the assault, a number of the terrorists were even able to get jobs working at the Olympic village which proved extremely useful as they planned the attack (Reeve, 2001) while others appeared able to gain entry to Olympic sites almost at will when they desired. The attack itself was launched during the second week of the Games. On September 5th 1972, the eight man strong terrorist team scaled the outer perimeter by pretending to be athletes returning from a party (and were assisted in doing so by genuine athletes who were also sneaking back in). The terrorists then stormed the accommodation area housing the Israeli team, killing two team members and taking a further nine hostage. Negotiations started between the terrorists and the West German authorities but the latter were poorly prepared for the crisis.

After several hours of negotiations, the authorities agreed to provide a passenger jet to fly the Black September team and their hostages out of the country. At the airport an attempt was made by the German police to overpower the terrorists and free the hostages. Planning and preparation for the rescue attempt, however, was extremely poor. The police at the airport, for example, had originally been told that there were just five terrorists and based their plans for the rescue on that number. They were only informed that there were actually eight terrorists minutes before the helicopters carrying the terrorists and hostages arrived, by which time it was too late to bring in extra resources or change the plan made. As a result, there were only five police snipers in position at the airport. The snipers themselves were inexperienced and had not received the specialist tactical training normally given to police SWAT officers (the SWAT 
team that eventually did arrive was sent to the wrong part of the airport and played no part in the crisis).

The resulting shootout, not surprisingly, was a debacle. Over a confused three hour period, five terrorists, one police officer and all nine hostages were killed at the airport. The three surviving terrorists were captured but were quickly freed when just three months later, Black September hijacked a Lufthansa jet in order to force the West German government to release them. Still shaken by the Munich experience, the government capitulated swiftly to the terrorists' demands and the three were released (Silke, 2001).

\section{ASSESSING TERRORIST INNOVATION AT MUNICH: (1) PRECONDITIONS}

Preconditions are those characteristics of terrorist organizations and of the environment in which they operate which make innovation more or less likely. Factors which are believed to be relevant in this regard can be the nature of leadership in the terrorist group; the level of resources the group enjoys (both in material and in skills/experience); and the group's structure. In the case of Black September in 1972, a number of preconditions are worth highlighting:

\section{Large organisation}

As has already been noted, the Black September Organisation (BSO) was effectively a covername used by Fatah during this period (Rubin, 1994). The internal dynamics within Fatah with regard to BSO operations are complicated and not easy to disentangle. 'BSO' operations were carried out by different factions within Fatah and there were varying levels of co-operation and rivalry between these factions. Nevertheless, BSO operations - including Munich - were able 
to draw upon Fatah's considerable resources in planning and conducting an operation. It has been estimated that between 40 to 100 people were actively involved in the planning, preparation and commission of the Munich assault. In 1972, Fatah could draw upon an estimated 10,000 to 15,000 active members, and the support and sympathy of a far larger constituency (Kurz, 2005). This allowed BSO to rapidly identify and recruit current members who had skills and experience directly relevant for the Munich attack (e.g. combat training, German language skills, experience of living in West Germany, etc.). Combined these factors significantly increased the likelihood of success.

\section{Well-resourced}

The Munich attack was not an expensive operation for BSO to carry out. The overall cost has been estimated at no more than $\$ 15,000$ (or approximately $\$ 90,000$ in 2019 prices). ${ }^{2}$ While this is a modest price it would still have exceeded the sums available for many smaller terrorist groups. In 1972, PLO funding came from a variety of sources and has been estimated at possibly being around $\$ 300$ million per annum. It certainly rose well in excess of this sum later in the 1970s. A sum of $\$ 15,000$ is not difficult to arrange in such circumstances and none of the terrorists involved reported that financing was a problem. Indeed, it seems that the team actually had too much money and they returned over $\$ 500$ to the organisation just before the assault was launched. 
BSO was a well-trained organisation by the standards of most terrorist groups. The organisation had access to training camps in Lebanon and Libya and some of the training for the Munich was directly facilitated by state sponsors.

Possessed safe-havens and state sponsorship

BSO was able to operate from a wide range of safe-havens. In 1972, the major safe-havens were located in Lebanon, Syria, Egypt, Algeria and Libya. There was also a smaller presence in Iraq (Gilbert, 2002). From these bases, the terrorists were able to rest, train and organise. Most of the team had been based in Lebanon when they were selected for the Munich attack and then were sent for specialist training at a training camp in Libya. The high level of state support that the organisation enjoyed greatly facilitated its ability to carry out operations.

Clear leadership - strong hierarchical structure

The Munich plot enjoyed clear and strong leadership. The central figure was Abu Iyad, who had been one of Fatah's founding members and was the organisation's chief of intelligence. He was regarded by some as second only to Yasser Arafat in terms of seniority within Fatah (Taylor, 1993). It is virtually certain that the Munich operation had Arafat's blessing though he was not involved in the active preparation for the attack. In his Black September operations Abu Iyad surrounded himself primarily with colleagues who had been his sub-ordinates in Fatah's intelligence wing. Abu Daoud played the next most senior role in the planning of the operation and was a strong supporter of Abu Iyad. Thus the leadership team involved in the 
plot had sufficient authority to rapidly access and direct the resources available to Fatah, but also enjoyed strong working relationships and good levels of communication. In contrast, relations among senior members in other areas of Fatah were often fractious, characterised by rivalry and mistrust.

\section{Currently engaged in active campaign in theatre}

BSO had been engaged in a campaign of terrorist attacks in Western Europe for over a year prior to Munich. Thus the organisation had established a network of operatives, intelligence and supporters in the region. German police estimated that at the time of Munich attack BSO could draw upon the active support of some 80 - 120 sympathisers who were living in West Germany. Prior to the Munich attack, 44 percent of BSO attacks in Europe in 1972 were carried out in West Germany. (In contrast, none of the group's attacks in 1971 were in West Germany). This was by far the country where BSO was most active and as a result the group possessed a great deal of experience of preparing and launching attacks in the region. That BSO was so active in West Germany in 1972 should have acted as a potential warning sign to the authorities with regard to the Olympics which was unquestionably the most high profile event in the country that year.

\section{High level of tactical success}

Overall, the BSO appeared to be enjoying a high level of tactical success. Most operations carried out by the group were done so without the attack team being captured and killed. The exception was the hijacking of Sabena flight 571 from Brussels to Tel Aviv. Though the takeover phase of the hijacking was successful, all of the terrorist team were subsequently 
killed or captured after the plane landed in Israel. One hostage was fatally injured in the rescue attempt but the other 96 hostages were freed unharmed (Reeve, 2001). Overall, the event was seen as a major victory for the Israelis and a significant set-back for BSO. Otherwise the BSO campaign was largely a successful one albeit relatively low profile. Most of the attacks resulted in no deaths and often tended to be against oil refineries or pipelines and manufacturing companies.

\section{ASSESSING TERRORIST INNOVATION AT MUNICH: (2) CAUSES OF INNOVATION}

As outlined earlier, causes are those factors that directly influence the group's decision to innovate. These may include new security environments, factional competitors, or a new strategic direction that requires an escalation in the violence (though it is not concerned with the causes of the terrorist campaign or conflict itself).

\section{Causes of innovation internal to the terrorist organization}

Ability of senior figures to communicate

Any serious analysis of terrorist decision-making recognises that chance plays a role in why some attacks happen and others never take shape. In their separate autobiographies both Abu Iyad and Abu Daoud say that the initial decision to attack the Olympics was made at a meeting in Rome in early July 1972 (roughly seven weeks before the actual attack). In support of this claim there is clear evidence that most of the direct preparation for the attack took place after this date (e.g. the selection of the support team and their dispatch to Libya for training; the 
arrival of the two team leaders in Munich; the smuggling of weapons into Munich; etc.). It is also worth noting that the most extensive and detailed analyses of the Munich attack by investigative journalists also accept that the Rome meeting occurred (e.g. Reeve, 2001; Klein, 2005).

At this meeting at a coffee shop were three of the most senior members of Black September: Abu Iyad - the effective leader of BSO; Abu Daoud and Fakhri al Umari both senior commanders who had received specialist intelligence training in Cairo in 1969 and who had been hand-picked by Abu Iyad. Abu Iyad describes that over coffee the group discussed a newspaper story that the International Olympic Committee had ignored two requests from a Palestinian Youth delegation to attend the Games. After the attack, the Olympic Committee would say that they had no record of receiving such letters (Schiller and Young, 2010, p.195). At the meeting it was proposed to try to attack the Games in retaliation for this snub.

Overall, it seems clear that these senior figures enjoyed a good ability to communicate and were open to fresh ideas from each other. Abu Iyad, for example, describes himself as having been initially sceptical about the feasibility of the Munich attack, but was convinced by his discussions with the other two men. As the plans for the plot progressed, the senior figures were able to meet on a number of occasions in different countries to discuss progress on the attack and co-ordinate activity and resolve any problems. The good personal interactions of the senior leadership combined with their ability to communicate regularly face-to-face as the plot progressed greatly assisted the planning and preparation for the attack. 
Openness to varied tactics

As figure 1 highlights the tactics used by Black September in their 1971-72 campaign (prior to Munich) was varied. The methods used ranged from shootings, large and small-scale bombings, to hostage-taking. The group was adopting a flexible approach in how it carried out operations and in the weapons and targets selected.

Figure 1: Pre-Munich Methods of Black September Attacks

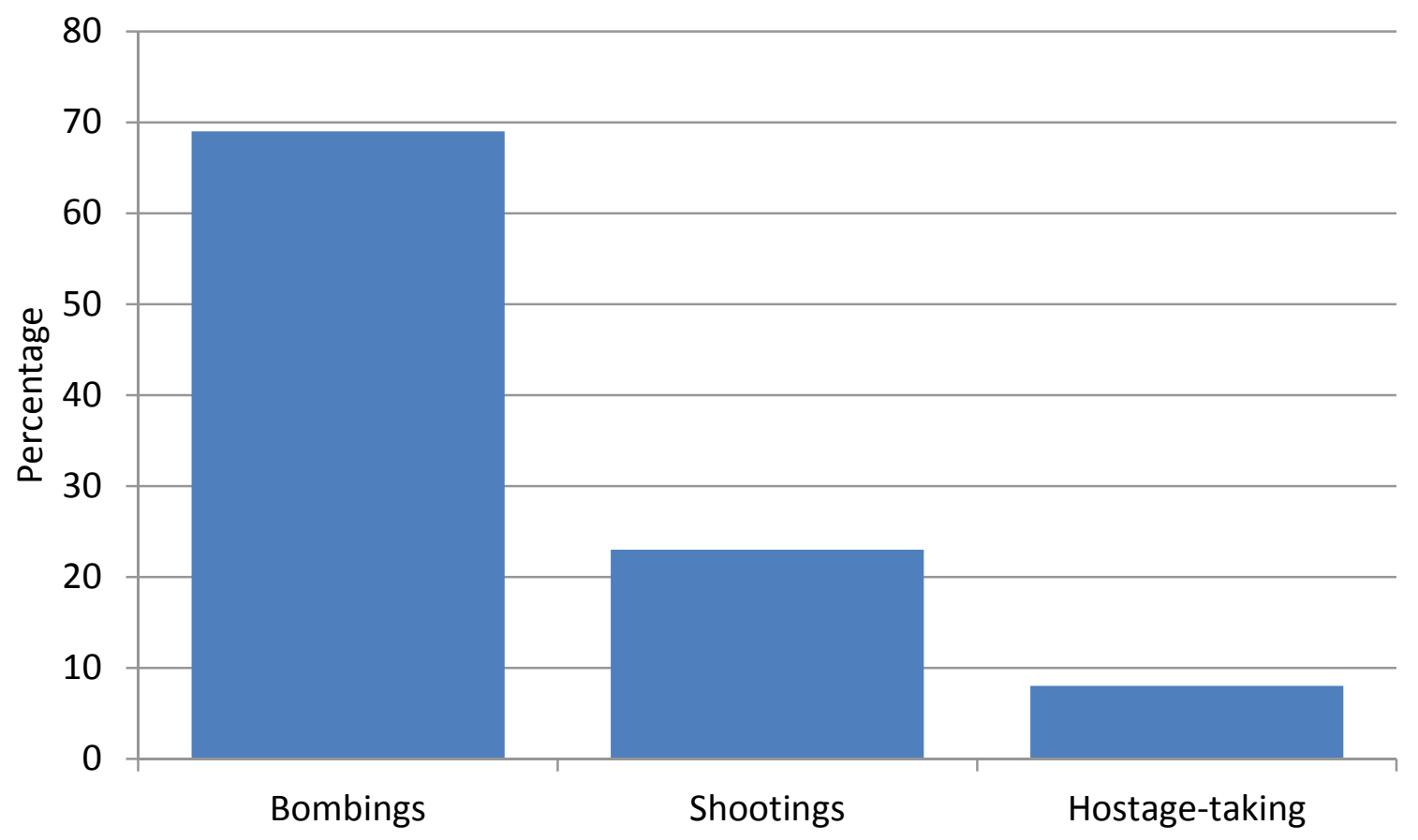

\section{Causes of innovation external to the terrorist organization}


Competition

Mia Bloom (2005) has highlighted that competition between terrorist organisations can be an important factor in the decision making and strategies of the groups. There is evidence that such competition was a factor in the planning for Munich. In 1969 Palestinian groups carried out an estimated 3,900 attacks against Israel (most of which were launched from Jordan and Lebanon) and a large proportion of these were organised by Fatah. In 1970 this figure also passed 3,000 attacks before the crackdown by the Jordanian army in the Summer against Palestinian militants (Asprey, 1994). The crackdown resulted in the deaths of nearly 3,000 militants and pushed the Palestinians almost entirely out of Jordan. In the aftermath, the Palestinians retreated to Lebanon as their new main base, but Fatah found that it no longer had the capacity to wage the same high intensity guerrilla actions that had marked the previous 20 months.

While Fatah was regrouping other Palestinian groups remained very active and in particular both the Popular Front for the Liberation of Palestine (PFLP) and its splinter group the Popular Front for the Liberation of Palestine - General Command (PFLP-GC) were heavily involved in international terrorism and both carried out some very high profile attacks in 1971 and 1972 , including a number of hijackings. Dolnik (2007) has highlighted that the PFLP and the PFLPGC were competing against each other during this phase and both were trying to outperform the other in terms of carrying out the most high profile and successful attacks. The impact of this was not lost on Fatah which in comparison seemed to be almost moribund. Part of the objective of the Black September campaign, then, was to demonstrate that Fatah could be just as effective as the PFLP and PFLP-GC. Prior to Munich however, the Black September 
campaign of 1972 was not an especially high profile one and its most prominent attack - the hijacking of Sabena flight 571 - was widely seen as a near complete failure.

Relationships among terrorist groups who operate within the same environment can lead to cooperation but can also lead to competition and rivalry. Competition between organizations with similar ideologies and causes is common and is motivated by the need to be able to claim legitimacy and monopoly over 'the cause.' The combination of competition, and the constant pursuit of security forces can put pressure on each of these groups to innovate in order to demonstrate superiority over rival groups. For instance, the BSO and the PFLP were in constant competition. The Popular Front for the Liberation of Palestine (PFLP) lacked a distinct ideology and had a relatively small membership compared to other Palestinian organizations. This led it to focus on spectacular operations, disproportionate to its size and support base in order to acquire a distinctive group identity among its peers. Thus, an audacious attack against the Olympics, could do a great deal in re-establishing the movement's prominence over its smaller - but effective - rivals.

\section{Media coverage}

For terrorists, an attack which receives a great deal of media attention is usually seen as much more successful than an attack which receives relatively little (even if the human casualties and physical damage caused by both attacks are similar). Indeed, even if an attack results in the death or capture of all the terrorists involved it can be still be regarded as highly successful if it has received intense international media attention (Silke, 2011). In planning for Munich, Black September were keenly aware that there would be intense media interest in the Games 
and as a consequence there would be intense coverage of a successful attack. Tapping into this media coverage was one of the three key objectives Abu Iyad had for the attack.

In the end, it has been estimated that approximately 900 million people in at least 100 countries witnessed the event on television while the crisis unfolded. Sanan (1996) estimated that over one quarter of the world's population became aware of the attack through one form of media or another. In one day, proclaimed Yasser Arafat later, the Palestinian cause gained more attention than any number of international conferences.

In a communiqué issued one week after the attack, Black September boasted:

In our assessment, and in light of the result, we have made one of the best achievements of Palestinian commando action. A bomb in the White House, a mine in the Vatican, the death of Mao Tse-tung, an earthquake in Paris could not have echoed through the consciousness of every man in the world like the operation at Munich. The Olympiad arouses the people's interest and attention more than anything else in the world. The choice of the Olympics, from the purely propagandistic viewpoint, was $100 \%$ successful. It was like painting the name of Palestine on a mountain that can be seen from the four corners of the earth. ${ }^{3}$

Whether the terrorist planners expected the operation to have quite such a massive media impact is unclear. They certainly appreciated that media interest would be very sizable if the operation was successful, but it is likely that even they were taken back by the sheer scale of the coverage that the attack received. 
Any assessment of Munich needs to highlight the extreme vulnerability of the games to attack. Investment in security was very low at just $\$ 2$ million (in comparative terms by far the lowest sum spent on security for a modern Olympics). This translates as just over $\$ 11.5$ million in 2016 prices. In comparison, the security budget for the 2012 Olympics was at least $\$ 1.384$ billion and some estimates put it closer to $\$ 2$ billion. Thus, in real terms, for every $\$ 1$ the Germans spent on security for the Munich Games, the UK spent at least $\$ 138$ (Richards, Fussey and Silke, 2011).

While some 2,000 security staff were hired for the Munich Games, these individuals were unarmed and were tasked to maintain a friendly appearance and atmosphere. In other regards, physical security systems were lax and easily penetrated by unauthorised individuals. Journalists (as well as terrorists) found that they could easily access restricted areas and buildings simply by donning a tracksuit and pretending to be athletes. The Black September team were regularly able to gain access to restricted areas in the run up to the attack, and indeed on the morning before the actual attack, one team member was discovered inside the building housing the Israeli athletes and was able to bluff his way out of the encounter without raising suspicion. Two members were also able to gain employment on the site at very short notice and without proper vetting.

Explicit concerns about the security for the Israeli team had been raised before the Games. Shmuel Lalkin, the head of the Israeli Olympic Delegation, raised security concerns on a number of occasions with both the West German authorities and with the Israeli authorities (Klein, 2005). These concerns were ignored and Lalkin found himself criticised for his efforts 
and told to focus on sporting issues. Some within the German police though had also raised the possibility of a Palestinian hostage-taking attack against the Israeli team during the Olympics. This threat, however, was dismissed by senior figures as unrealistic. When the proposer persisted in arguing that the risk needed to be taken seriously he was fired (Schiller and Young, 2010).

Thus the Olympics despite its massive profile presented what was ultimately a very vulnerable target. This was due to three factors: (1) a profound lack of investment in security resources; (2) a lax security culture and regime which made poor use of the resources which were available; and (3) the systematic side-lining of any voices who criticised security arrangements or highlighted vulnerabilities.

When Black September carried out their initial reconnaissance around Munich in mid-July they quickly realised that the security was weak and easily penetrated. Had these initial examinations found more robust security measures in place it is highly likely that an attempt to carry out an attack would not have occurred and Black September would have switched its energy to attacking other targets.

\section{WAS THE MUNICH ATTACK PREDICTABLE?}

The short answer is, yes. A German police psychologist did predict the attack before Black September had even identified the Olympics as a target. In preparing for Munich, the West German authorities commissioned a security review to examine potential security scenarios the Games might be threatened with. In particular 26 scenarios were developed and highlighted (Wolff, 2002). Scenario 21 suggested that a group of Palestinian terrorists would penetrate the 
Olympic village and try to take members of the Israeli team hostage. The scenario proposed the event would start during darkness and that the terrorists would kill one or two hostages at the beginning to demonstrate their seriousness. The terrorists would then make a series of demands (one of which would be the release of Palestinian prisoners in Israeli jails). The scenario predicted that the terrorists would not be willing to surrender the hostages if these demands were refused. The authorities rejected this scenario, informing the creator that they wanted something more realistic.

As figure 2 highlights even the most cursory review of Black September attacks in 1972 should have raised concerns regarding the potential threat. Black September carried out no attacks in West Germany in 1971 , yet in the run up to the September $5^{\text {th }} 1972,44$ percent of all Black September attacks took place in that country. That West Germany had become the most active theatre for Black September that year should have been noted by the authorities.

Linked to this, Black September's attacks in 1971 had exclusively targeted Jordanian targets and no Israeli targets were attacked. From the beginning of 1972, however, the movement had clearly switched its focus to Israeli-linked targets with 89 percent of all attacks in the run-in to Munich being against Israeli-linked targets. Klein (2005) highlights that even the Israeli intelligence services were extremely slow to recognise how Black September targeting had changed and by mid-1972 they were still continuing to assess the group as primarily focused on hitting Jordanian targets. 
Figure 2: Pre-Munich Characteristics of Black September Attacks

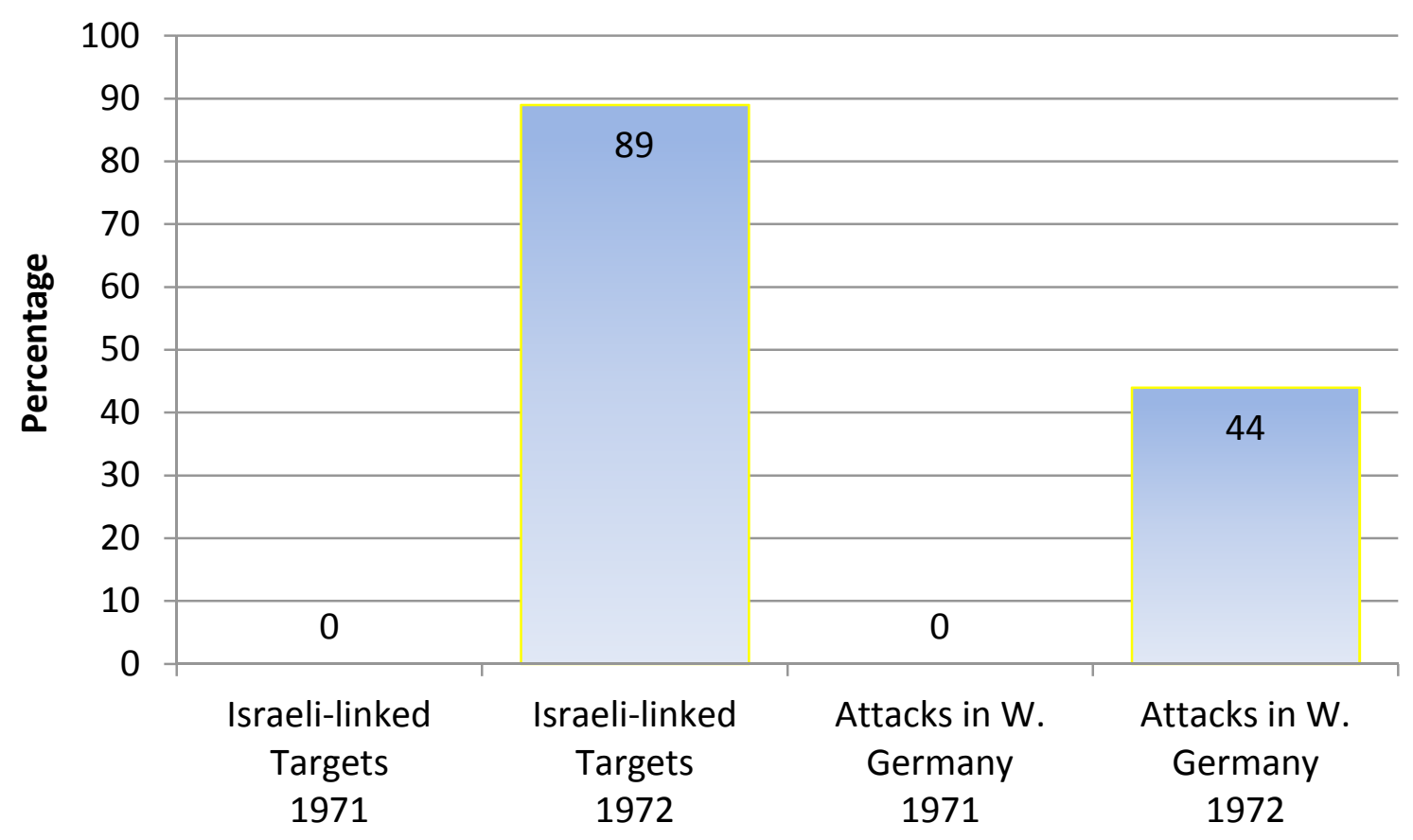

Given the dramatically different profile of Black September attacks in 1972 compared to 1971, much more awareness of the potential threat to Israeli targets in West Germany should have been shown. In such circumstances, the threat assessment described in scenario 21 should have been treated as much more credible. Instead, those in senior positions appeared to be wholly unable to appreciate the significance of the major change in activity which Black September had clearly demonstrated in the first eight months of 1972.

\section{CONCLUSIONS}

In thinking about innovation in the case of the Munich attack, three factors stand out which explain Black September's ability to develop and carry out such a high impact operation. First, the BSO - or rather Fatah which it was effectively an off-shoot of - was a very large organisation, with considerable resources and which also enjoyed state support, training and facilitation. At the time, Fatah boasted about 15,000 active members who were willing to be 
involved in militant action. The numbers who were willing to support the group and its activities in less direct methods was considerably larger. This meant that the funding required for the operation was easily obtained and that suitable individuals to carry out the attack could be quickly identified and tasked with appropriate training and preparation.

Two, the senior figures involved in the planning and development of the operation enjoyed good levels of communication, good levels of trust and were open to exploring new tactics and approaches.

Third, the incredibly poor threat assessment and dismal security surrounding the Olympics in general and the Israeli team in particular was perhaps the single most important factor. Had the Black September planners encountered tougher security arrangements in their initial reconnaissance of the Olympic site, the plan almost certainly would have been dropped at an early stage and Black September would have switched its attention elsewhere. The exceedingly vulnerable nature of the target combined with its very attractive profile acted as a powerful pull factor in the planning phase of the operation, and gave the terrorists a great advantage in the execution of the attack.

Overall, Munich is perhaps most clearly seen as an opportunity which was almost handed to Black September on a plate. Once the organisation had made the creative leap to consider the Olympics as a potential target, the surprising vulnerability of the target greatly facilitated every subsequent step and effectively pulled Black September deeper into conducting an attack. Munich is a terrorist attack which never should have happened. That it did happen ultimately tells us at least as much about the remarkably poor preparations of the authorities, as it does about the innovation of the terrorists. 


\section{REFERENCES}

Afzal, A. and Filippidou, A. (2017) Terrorism and Technology. Turkey: NATO.

Al-Qurashi, Abu 'Ubeid, (2002) Al-Ansar: For the Struggle Against the Crusader War, Issue 4, February 27, 2002, trans. MEMRI, Al-Qa'ida Activist, Abu 'Ubeid Al-Qurashi:

Comparing Munich (Olympics) Attack 1972 to September 11, Special Dispatch Series, No. 353, March 12, 2002.

http://memri.org/bin/articles.cgi?Page=archives\&Area $=\mathrm{sd} \& \mathrm{ID}=\mathrm{SP} 35302$

Asprey, R. (1994) War in the Shadows. London: Little \& Brown.

Bloom, M. (2005) Dying to kill: The Allure of Suicide Terror. New York: Columbia University Press.

Clarke, R. and Newman, C. (2006), Outsmarting the Terrorists. London: Praeger Security International.

Cornish, D. and Clarke, R. (1986) The Reasoning Criminal. New York: Springer-Verlag.

Cropley, D., Kaufman, J. and Cropley, A. (2008) Malevolent creativity: A functional model of creativity in terrorism and crime. Creativity Research Journal, 20(2): 105-115.

Daoud, A. with Du Jonchay, G. (2002) Palestine: From Jerusalem to Munich, from Munich to Jerusalem. New York: Arcade Publishing. 
Dobson, C. (1974) Black September: its short, violent history. London: Robert Hale.

Dolnik, A. (2007) Understanding Terrorist Innovation. London: Routledge.

Drake, C. (1998) Terrorists’ Target Selection. London: Macmillan.

English, R. (2013) Terrorist innovation and international politics: Lessons from an IRA case study. International Politics, 50(4): 496-511.

Faria, J. (2006) Terrorist innovations and anti-terrorist policies. Terrorism and Political Violence, 18(1): 47-56.

Gilbert, M. (2002) The Routledge Atlas of the Arab-Israeli Conflict, Seventh Edition. London:

Routledge.

Gill, P. (2017) Tactical Innovation and the Provisional Irish Republican Army. Studies in Conflict \& Terrorism, 40(7): 573-585.

Gill, P., Horgan, J., Hunter, S. T. and D. Cushenbery, L. (2013) Malevolent Creativity in Terrorist Organizations. The Journal of Creative Behavior, 47: 125-151.

Goerzig, C. (2019) Terrorist learning in context - the case of Al Qaeda in the Islamic Maghreb. Critical Studies on Terrorism, advance online publication 20 April, DOI: $10.1080 / 17539153.2019 .1596623$ 
Hafez, M. and Rasmussen, M. (2012) Terrorist Innovations in Weapons of Mass Effect, Phase II. Monterey, CA: Naval Postgraduate School.

Herwig, H. (1998) Innovation Ignored: the submarine problem - Germany, Britain and the United States 1919-1939, in Murray, Williamson R. and Millet, Allan R., Military Innovation in the Interwar Period. London: Cambridge University Press.

Hoffman, B. (1998) Inside Terrorism. London: Victor Gollancz.

Homeland Security Institute, (2007) Underlying Reasons for Success and Failure of Terrorist Attacks: Selected Case Studies.

http://www.homelandsecurity.org/hsireports/reasons_for_terrorist_success_failure.pdf

Horowitz, M. (2010) Nonstate actors and the diffusion of innovations: The case of suicide terrorism. International Organization, 64(1): 33-64.

Hsu, H.Y. and Apel, R. (2015) A Situational Model of Displacement and Diffusion Following the Introduction of Airport Metal Detectors. Terrorism and Political Violence, 27(1): 29-52.

Iyad, A. with Rouleau, E. (1981) My Home, My Land: A Narrative of the Palestinian Struggle. New York: Times Books. 
Jackson, B., Baker, J. and Cragin, K. (2005) Aptitude for Destruction: Case studies of organizational learning in five terrorist groups (Vol. 2). Santa Barbara, CA: Rand Corporation.

Jackson, B. and Loidolt, B. (2013) Considering al-Qa'ida's Innovation Doctrine: From Strategic Texts to Innovation in Practice. Terrorism and Political Violence, 25(2): 284-310.

Jacobs, S. (1998) The Nuclear Threat as a Terrorist Option. Terrorism and Political Violence, 10(4): 149-163.

Kettle, L. and Mumford, A. (2017) Terrorist learning: a new analytical framework. Studies in Conflict \& Terrorism, 40(7): 523-538.

Klein, A. (2005) Striking Back: The 1972 Munich Olympics Massacre and Israel's Deadly Response. New York: Random House.

Knight, S., Keane, C. and Murphy, A. (2015) Adversary Group Decision-Making Regarding Choice of Attack Methods: Expecting the Unexpected. Terrorism and Political Violence, 29(4): 713-734.

Kurz, A. (2005) Fatah and the Politics of Violence: the Institutionalization of a Popular Struggle. Brighton: Sussex Academic Press.

Moghadam, A. (2013) How al Qaeda innovates. Security Studies, 22(3): 466-497. 
Newman, G. and Hsu, H. (2012) Rational Choice and Terrorist Target Selection. In U. Kumar and M. Mandal (eds.) Countering Terrorism: Psychosocial Strategies. London: Sage, pp.227249.

Ranstorp, M. and Normark, M. (2015) Understanding Terrorism Innovation and Learning: Al Qaeda and Beyond. Abingdon, Oxon: Routledge.

Rasmussen, M. (2017) Terrorist learning: A look at the adoption of political kidnappings in six countries, 1968-1990. Studies in Conflict \& Terrorism, 40(7): 539-556.

Rasmussen, M. and Hafez, M. (2010) Terrorist innovations in weapons of mass effect: Preconditions, causes and predictive indicators. Washington, DC: The Defense Threat Reduction Agency (Report No. ASCO 2010-019).

Reeve, S. (2001) One Day in September: The Full Story of the 1972 Munich Olympics Massacre and the Israeli Revenge Operation Wrath of God. New York: Arcade Publishing.

Richards, A., Fussey, P. and Silke, A. (eds.) (2011) Terrorism and the Olympics. London: Routledge.

Rubin, B. (1994) Revolution until Victory? The Politics and History of the PLO. Cambridge: Harvard University Press.

Sanan, G. (1996) Olympic Security 1972-1996: Threat, response and international cooperation. PhD Thesis, University of St. Andrews. 
Sayigh, Y. (1997) Armed struggle and the search for state: The Palestinian national movement, 1949-1993. Oxford: Oxford University Press.

Schiller, K. and Young, C. (2010) The 1972 Munich Olympics and the Making of Modern Germany. Berkeley: University of California Press.

Silke, A. (2001) When Sums go Bad: Mathematical Models and Hostage Situations. Terrorism and Political Violence, 13(2):49-66.

Silke, A. (2003) Beyond Horror: Terrorist Atrocity and the Search for Understanding-- The Case of the Shankill Bombing, Studies in Conflict \& Terrorism, 26(1): 37-60.

Silke, A. (2011) Understanding Terrorist Target Selection. In: A. Richards, P. Fussey and A. Silke (eds.) Terrorism and the Olympics: Major Event Security and Lessons for the Future. London: Routledge.

Taylor, M. (1988) The Terrorist. London: Frank Cass.

Taylor, P. (1993) States of Terror. London: BBC Books.

Tishler, N. A. (2017) Trends in Terrorists' Weapons Adoption and the Study Thereof. International Studies Review, 20(3): 368-394. 
Weinberg, L. (2008) Two Neglected Areas of Terrorism Research: Careers after Terrorism and How Terrorists Innovate. Perspectives on Terrorism, 2(9).

Wolff, A. (2002) When the terror began. Time, (August 25)

http:/www.time.com/time/europe/magazine/2002/0902/munich/index.html

\section{Notes}

${ }^{1}$ As recorded by the START Global Terrorism Database which included incidents from 1970 - 2017: http://www.start.umd.edu/gtd/

${ }^{2}$ For an indication of just how cost effective terrorism can be, it is worth looking at how much it costs to advertise on television during the Olympics. On average during the 2008 Beijing Olympics, it cost advertisers $\$ 750,000$ for every 30 seconds in the US market alone. The $\$ 90,000$ (in modern prices) BSO spent on the Munich attack would have bought them barely 3 seconds. The actual media coverage the attack received on September 5 th was potentially worth in the order of $\$ 1.8$ billion (in modern prices) if not more. It is worth remembering that this figure only applies to US coverage. Worldwide the total worth was probably closer to $\$ 3$ billion.

${ }^{3}$ Some sources attribute this communique to George Habash, the leader of the PFLP, but the majority view is that it did indeed come from Black September. 